\title{
当教室過去16年間の気管・気管支異物の集計
}

野々山勉, 原田輝彦, 大川 親久 鵜 飼 幸太郎, 坂 倉 康 夫

\section{A Statistical Review of Clinical Cases with Tracheo-Bronchial Foreign Bodies over 16 Years}

\author{
Tsutomu Nonoyama, M.D., Teruhiko Harada, M.D., Chikahisa Okawa, M.D., \\ Kotaro Ukai, M.D., and Yasuo Sakakura, M.D.
}

Department of Otorhinolaryngology, Mie University School of Medicine, Mie

\begin{abstract}
A statistical study was made of 69 cases of tracheo-bronchial foreign bodies treated at our clinic during the 16 years from 1978 to 1994 . Fifty-five cases $(80 \%)$ were under 3 years of age and 38 cases (55\%) were one-year-old babies. The foreign bodies were found in the right bronchus in 24 patients, in the left bronchus in 32 patients, and in the trachea in 6 patients. Of the various kinds of foreign bodies removed, peanuts predominated (34 cases, 49.3\%). The foreign bodies were removed by means of a ventilation bronchoscope under general anesthesia. Most of the cases were treated within a few days successfully. However, the longest period of lodgement was 87 days.
\end{abstract}

Key words : tracheo-bronchial foreign bodies, statistics, ventilation bronchoscope

\section{I 。はじめに}

気管・気管支異物は日常臨床においてしばし ば遭遇するが，耳鼻咽喉科領域のなかでも緊急 度の高い救急疾患であり，直接生命に危険を及 ぼす場合も少なくない。われわれは過去に1970 年 4 月から1978年 3 月までの 8 年間に三重大学 胸部外科および同耳鼻咽喉科において取り扱っ た気管・気管支異物症例 31 例について検討し， 特に開胸手術を要した症例および死亡例を中心 にその対策について考察した ${ }^{11}$ が，今回さらに 1978年 4 月から1994年 3 月までの16年間に経験 した気管・気管支異物症例について統計的観察 を行ったので若干の文献的考察を加えて報告す る。

三重大学医学部耳鼻咽喉科学教室

別刷請求：干514 三重県津市江戸橋2-174

三重大学医学部耳鼻咽喉科 野久山勉 投稿受付：1996年 9 月 24 日

\section{II ．統計的観察}

1. 年度別・性別症例数

16年間で69例と年平均約 4 例の発生があり, 87 年度以降は93年度を除き症例数は減少傾向に あった。性別では男性44例, 女性25例で男女比 はおよそ $2: 1$ と諸家の報告と同様の傾向を示 した（図 1)。

\section{2 . 年齢分布}

年齢は69例中 3 歳以下が55例 (80\%) を占め, その中でも 1 歳台が 38 例（55\%）と過半数を占 めていた。15歳から50歳代の中間層は少なく, 60 歳以降の高齢者に 5 例認められた（図 2 )。

\section{3 . 異物の種類}

異物の種類は多彩で 25 種類に及ぶが，なかで もピーナッツが多く69例中34例（49.3\%）と約 半数を占め, 豆類は大豆などピーナッツ以外を 含めると 41 例 $(59.4 \%)$ と過半数を占めていた (表 1 )。不明の 1 例を除く68例中X線透過性異 
日気食会報，48（3），1997

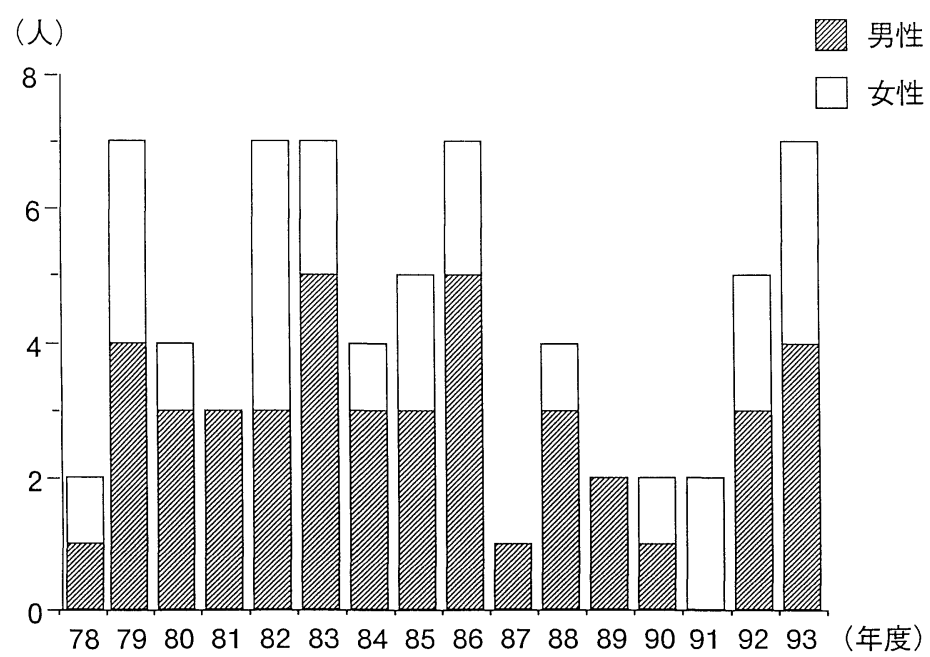

図 1 年度別・性別症例数

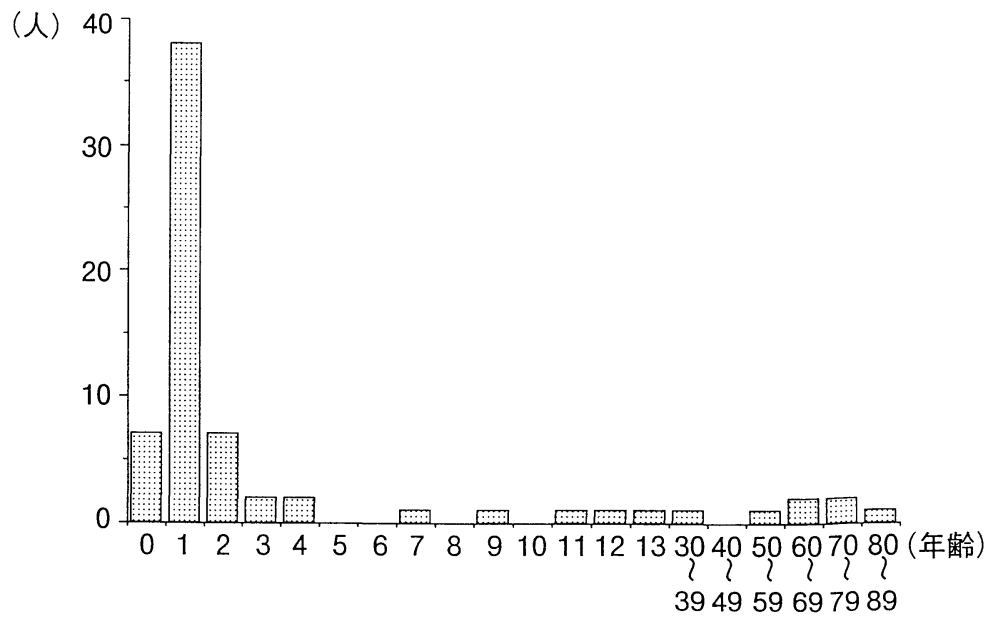

図 2 年齢分布

表 1 異物の種類

\begin{tabular}{lrll}
\hline ピーナッツ & 34 & 魚骨 & 1 \\
大豆 & 4 & 玩具 & 3 \\
アーモンド & 1 & 待ち針 & 2 \\
枝豆 & 1 & 釣針 & 1 \\
ソラマメ & 1 & 安全ピン & 1 \\
栗 & 2 & 画びょう & 1 \\
ブドウ & 1 & 義歯 & 1 \\
リンゴ & 3 & 歯牙 & 1 \\
桃 & 1 & 柬科の needle & 1 \\
アラレ & 1 & 石 & 1 \\
スナック菓子 & 1 & 銀紙 & 2 \\
さきいか & 1 & クレヨン & 1 \\
アジの干物 & 1 & 不明 & 1 \\
\hline \multicolumn{2}{r}{} & \multicolumn{2}{c}{ 計 } \\
\hline
\end{tabular}

物は56例 (82.4\%)，非透過性異物は12例（17.6 \%) と大多数がX線透過性異物であった。異物 を食物と非食物とにわけると，不明の 1 例を除 き食物 53 例 $(76.8 \%)$ ，非食物 $(21.7 \%)$ と食物 が多く，年齢との関係をみてみると食物は53例 中 3 例を除きすべてが 4 歳以下の乳幼児である のに対し, 非食物は 6 歳以上の年長児あるいは 成人に多く認められた（表 2 )。

\section{4. 異物の介在部位}

異物の介在部位が明確な62症例について検討 した。介在部位は一般的には右側に多いとされ るが, 今回の検討では気管 6 例, 右気管支 24 例, 
表 2 異物の種類と年齢

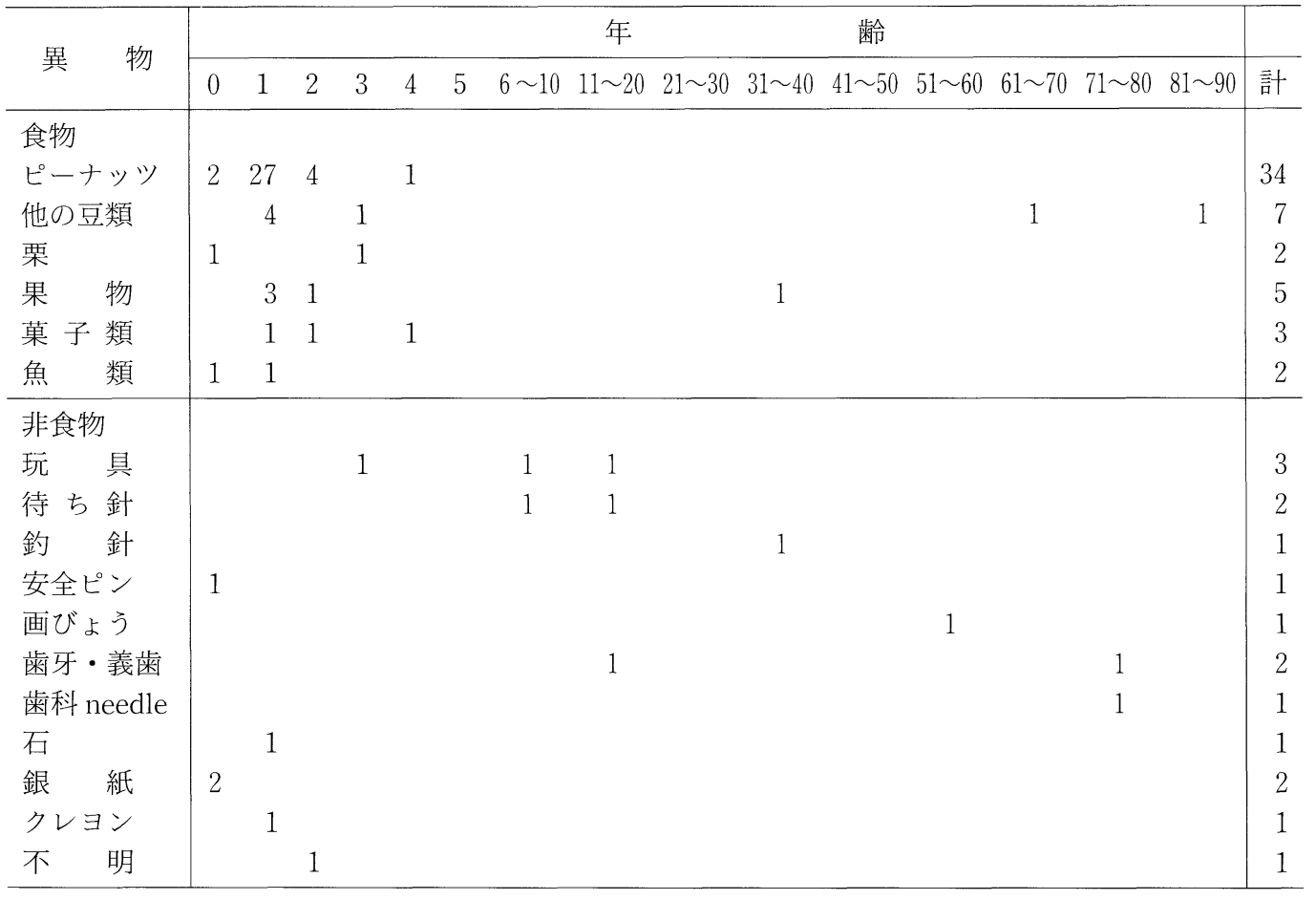

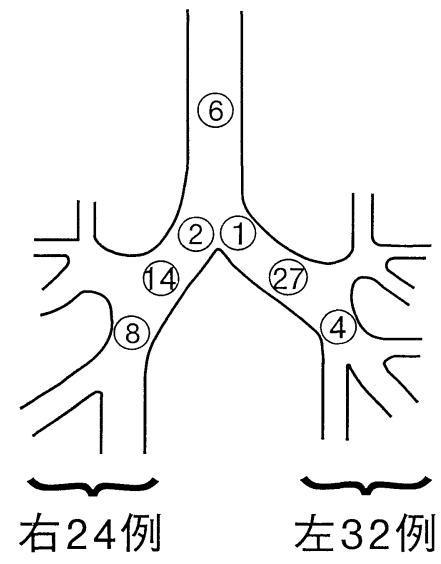

図 3 介在部位

表 3 受診経路

\begin{tabular}{lrl}
\hline 当院直接受診 & 3 例 & $(4.3 \%)$ \\
小 児 科 & 34 例 & $(49.3 \%)$ \\
他の耳鼻咽喉科 & 18 例 & $(26.1 \%)$ \\
内科あるいは外科 & 12 例 & $(17.4 \%)$ \\
芷 科 & 2 例 & $(2.9 \%)$ \\
\hline \multicolumn{1}{c}{ 計 } & 69 例 & \\
\hline
\end{tabular}

表 4 異物の介在日数

\begin{tabular}{c|c}
\hline 介在日数 $($ 日) & 症 例 数 (例) \\
\hline 0 & 18 \\
1 & 12 \\
2 & 9 \\
3 & 5 \\
4 & 3 \\
5 & 1 \\
6 & 1 \\
7 & 0 \\
8 & 1 \\
9 & 0 \\
$10 \sim 19$ & 7 \\
$20 \sim 29$ & 1 \\
30 以上 & 11 \\
\hline 計 & 69 \\
\hline
\end{tabular}

左気管支32例と左に多く認められた（図 3 )。

\section{5. 受診経路}

直接当院を受診した例は少なく 3 例（4.3\%） にすぎず，大部分が他院からの紹介によるもの で, 中でも最も多いのが小児科からの紹介で, 


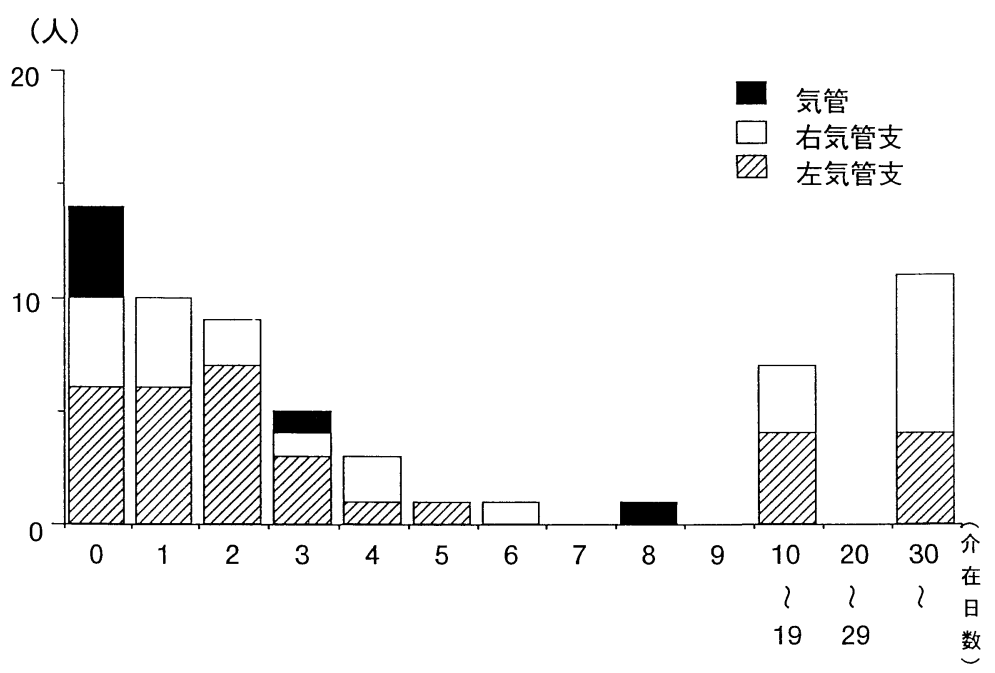

図 4 介在部位と介在期間

34例 $(49.3 \%)$ と約半数を占めた。続いて他の 耳鼻科18例 (26.1\%), 内科あるいは外科12例 (17.4\%)，歯科 2 例（2.9\%）の順であった（表 $3)$ 。

\section{6. 異物の介在日数}

異物の詋嚥から摘出までの期間を介在日数別 に示した (表 4 )。誤嚥の当日に摘出されている 例が最も多く，69例中18例（26\%）を占めてお り, 多くの症例では数日以内に除去されている。 しかし，1 カ月以上の長期介在例も11例（15.9 \%) と少なからず存在し，このうち10例は 1 力 月から 2 力月で摘出されているが 1 例は87日間 介在していた。長期介在例の種類は 11 例中 9 例 がピーナッツ， 1 例が50歳男性の釣針， 1 例が 87日間介在した10カ月男児の魚骨であった。部 位別にみると 7 例が右気管支， 4 例が左気管支 で右に多く認められた。

\section{7. 介在部位と介在期間}

異物の介在部位が明確な62症例について介在 部位を気管，右気管支，左気管支に分け介在日 数との関係を検討した(図 4 )。介在日数におい て左右の気管支に明らかな差は認められなかっ たが，気管異物は早期に摘出されていた。

\section{8. 胸部 $X$ 線所見}

胸部X線検查結果はその所見の記載が明らか な66例について検討した(表 5 )。66例中患側肺 気腫を示した例が最も多く 30 例, 患側無気肺が
表 5 胸部X線所見

\begin{tabular}{cr}
\hline 患側肺気腫 & 30 例 \\
患側無気肺 & 8 例 \\
びまん性陰影 & 6 例 \\
異物陰影 & 10 例 \\
異常なし & 12 例 \\
\hline 計 & 66 例 \\
\hline
\end{tabular}

表 6 摘出方法

\begin{tabular}{lr}
\hline 硬性気管支鏡 & 58 例 \\
気管支ファイバースコープ & 2 例 \\
開胸（待ち針・釣針） & 2 例 \\
自然喀出(桃・ぶどう・大豆・枝豆・玩具・銀紙 $)$ & 6 例 \\
その他 & 1 例 \\
\hline \multicolumn{1}{c}{ 計 } & 69 例 \\
\hline
\end{tabular}

8 例, びまん性陰影が 6 例, 異物陰影が 10 例, 異常なしが12例であった。患側肺気腫あるいは 患側無気肺を示した38例中 Holzknecht 徵候の 記載のあった例は 8 例（21.1\%）であった。

\section{9. 摘出方法}

摘出方法について表 6 に示した。69例中58例 が硬性気管支鏡，2例がファイバースコープ下 に摘出されており，開胸を要した例は 2 例であ つた。また，自然喀出例が 6 例あり，このうち 3 例は硬性鏡で異物が喀出され気管内にないこ 
とを確認しており, 残りの 3 例は胸部X線, 聴 診などの理学的所見により異物が喀出されたこ とを確認していた。その他の1例は先に述べた 異物の種類が確認できなかった例で, 自然喀出 に含まれるが異物の種類が確認されていないた めその他に分類した。摘出時の麻酔方法は 3 例 が局所麻酔下に行われていたが, 他はすべて全 身麻酔下に行われていた。局所麻酔の 3 例はす べて成人例であり，2 例はファイバースコープ 下に摘出された画びょうと歯科の needleで，1 例は硬性鏡下に摘出された義歯の症例であっ た。開胸を要した 2 例はそれぞれ待ち針と釣針 の誤嬹症例で， 2 例とも針先が気管支粘膜に刺 入し, 気管支鏡下の鉗子操作では摘出不可能で あったため本院胸部外科へ転科のうえ開胸術を 行ったものである。開胸術後の経過は 2 例とも に良好であった。気管切開を必要とした症例は 2 例あり，1例は上気管支鏡で摘出困難であっ たため気管切開後, 下気管支鏡にて摘出した症 例で，もう 1 例は硬性鏡施行後喉頭浮腫をきた し術後に気管切開を行った例である。なお，今 回検討した69例中死亡例はなかった。

\section{III. 考 察}

過去16年間に当科を受診した気管・気管支異 物症例は69例で，年平均 4 例の発生であったが 年間発生件数は各施設地域によりおよそ2例か ら10例とかなりの差がある2 6)。当院では1970年 から1978年にかけても気管・気管支異物の統計 を行っている が, 8 年間で31例であり, 年間発 生件数はほぼ同数であった。年次別発生頻度に 大きな変動はみられないとする報告が多い5 99 が，今回の検討では理由は定かでないが，87年 度以降93年度を除きやや減少傾向が見受けられ る。男女比は諸家の報告3 5,9,10 13) と同様におよ そ $2: 1$ であった。年齢分布では 3 歳以下が $80 \%$ と圧倒的であり他の報告と一致していたが，60 歳以降の高齢者にもやや多く二峰性を示した。

異物の種類は 25 種類におよび，食物と非食物 に分けると食物が $76.8 \%$ を占め，中でも乳幼児 では食物が圧倒的に多く，年長児あるいは成人 では非食物が多くなる傾向を示した。諸家の報 告1 7,9,10) と同様に最も多いのがピーナッツで約 半数を占め, 大豆など他の豆類を含めると 59.4
\%と過半数を占めた。また， 2 歳以下の年齢で は52例中 37 例 $(71.2 \%)$ が豆類であった。なお, 不明の 1 例は明らかなエピソードはなかったも のの著明な咳嗽と左肺の呼吸音減弱をきたし, $\mathrm{X}-\mathrm{P}$ 上左肺の気腫状変化と Holzknecht 徴候 を認めたため，気管支鏡を行ったところ左主気 管支に異物様物質を認めたが，換気の限界に達 し摘出できないまま終了した。しかし，その翌 日より呼吸音ならびに X-P 上の所見も改善し 4 日後再び気管支鏡を行ったところ前回確認し た異物は認められなかったという症例で，1回 目の麻酔覚醒時に自然喀出された可能性がある と思われる。

異物の介在部位では，右に多いという報 告 $4,6,7,15)$ が多いが, その理由として Jackson ら ${ }^{16)}$ は気管支の直径が右のが大きいこと, 気管 軸からの分岐角が右のが小さいこと，気管分岐 部が正中より左寄りに存在すること, 気管支に 入る空気量が右に多いこと, 気管筋の働きが関 係していること等をあげている。しかし，左に 多いという報告 ${ }^{11,12,19)}$, 左右差を認めないとす

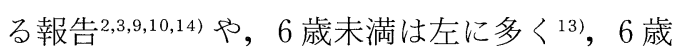
以上は右に多( ${ }^{5)}$ という報告もあり一定の見解 は得られていない。当科では右 24 例, 左 32 例と 左に多く, 年齢を考慮しても 6 歳未満, 6 歳以 上ともに左に多く認められ，気管支異物は左右 どちらにも生じ得ることを常に念頭に置く必要 があると考えられた。

誤嬹から異物摘出にいたるまでの期間では, 誤曣当日に摘出されている例が最も多く $26 \%$ を 占めて沶り，大多数が数日以内に摘出されてい たが，1 カ月以上の長期介在例も11例存在し, 最長は87日間介在した魚骨異物症例であった。 長期介在例は異物反応が弱い金属製異物が多 く, 開胸術が行われたものが多いという報告 ${ }^{17)}$ があるが，われわれの 1 力月以上の長期介在例 11 例では 9 例がピーナッツであり，釣針の 1 例 のみ開胸術を必要とした。摘出が遅れた症例で は, 詋嬹直後の症状が軽快してしまい, 数日し てから発生した頑固な咳嗽，喘鳴，発熱などを 心配して受診するケースが多く, 喘息, 肺炎, 気管支炎などど誤診されて長期にわたり抗生剂 投与を受けている症例もあり注意を要する。し たがって，保護者，医師ともに気管支異物につ 
いての知識を深め，常に念頭に置き早期発見に 努めるべきである。また，介在部位と介在期間 との関係では左右の気管支で差は認められなか ったが，気管異物は早期に摘出されており，呼 吸器症状が強く早期診断が可能であったためと 考えられた。

胸部X線検査は問診, 理学的検査にならび気 管支異物の診断において重要であるが，異物が X線非透過性であることは少なく，特に幼少児 においては大半がX線透過性異物であり, 当科 においても異物陰影がみられたのは10例のみで あった。したがって, 深吸気時と深呼気時にお のおの撮影し, 深吸気時に心縦陰影が偏位する 側を患側とする Holzknecht 徵候が重要視され る。しかし，幼少児に対して深吸気時と深呼気 時で正確に撮影することは必ずしも容易なこと ではなく,また,すべての症例に Holzknecht 徵 候が認められるとは限らず，田中ら ${ }^{2)} は 16$ 例中 Holzknecht 徵候を認めたのは 4 例のみと報告 している。さらに，誤嚥早期では異常を認めな い例が多いことから，問診にて異物吸引が明ら かな症例に対しては積極的に気管支鏡を行う必 要があると考えられる。

当教室では, 患側の肺気腫あるいは患側無気 肺を呈した症例38例中カルテに明らかな Holzknecht 徵候の記載のあった例は 8 例のみであ つたが，すべての症例に対して吸気時と呼気時 にX線撮影を行っているとは限らないため, こ のデータは参考值と考えたい。

また，びまん性陰影を呈した 6 例において異 物の種類をみてみると 4 例がピーナッツ， 1 例 がアラレ，1例がリンゴの異物であり，これら の症例の介在期間は長期介在例ばかりでなく数 時間で摘出されたものが 2 例, 1 日から 2 日が 2 例， 1 週間以上が 2 例で短時間でもびまん性 陰影をきたし得ると考えられた。

摘出方法については, 昭和40（1965）年代後 半からのventilation bronchoscope の普及に 伴い，全麻下の上気管支鏡による摘出が大半を 占めるようになったが, 当教室においても前回 の1970年からの 8 年間の報告で31例中 20 例が気 管支鏡で摘出されており，症例によってはventilation bronchoscope が用いられている。今回 の検討では69例中58例が気管支鏡下に摘出され
ており，このうち57例が全身麻酔下に ventilation bronchoscope を用いて摘出されていた。 また，前回の報告では20例中 5 例に開胸を行っ ており，4例がピーナッツ，1例が歯牙の症例 であったが，今回開胸を行った例は69例中 2 例 のみで，それぞれ待ち針と釣針の症例であり， ピーナッツはすべて気管支鏡下に摘出可能であ つた。下気管支鏡下に摘出した 1 例は歯牙の症 例で，上気管支鏡では鉗子での把持が困難であ つたため気管切開後下気管支鏡で摘出し得たも のである。

自然喀出の頻度は 1 〜 $\%^{20)}, 5.2 \%{ }^{18)}$ ある いは $6.2 \%$ といつた報告があるが，われわれの 結果では前回が $9.7 \%$, 今回が $8.6 \%$ と他の報告 に比し高率であった。また, 前回の報告では31 例中 3 例が死亡しているが, 今回の検討では死 亡例はなく, 近年の他の報告 $5,7,8)$ で死亡例は 減少しており, 診断技術の向上による早期発見 さらに麻酔法や気管支鏡・鉗子等の器具の発達 により摘出手技の安全性, 確実性が増したため と考えられる。

しかし, 減少傾向にあるとはいえ, 当地域で は例年節分の季節に気管支異物症例が集中する のが現状であり，直接生命に危険を及ぼす場合 も少なくないため, 諸家の指摘するごとく乳幼 児をもつ親への社会的啓蒙により発症の予防に 努めると同時に, 耳鼻咽喉科医のみならず他科 医における気道異物の認識を強化することによ り，早期発見・早期摘出の医療体制を築きあげ る必要があると考えられる。

\section{IV. まとめ}

1 ）過去 16 年間に気管・気管支異物と診断さ れた69例につき検討した。

2 ）69例中 38 例 (55\%) が1歳児であり，3 歳以下の症例が全体の $80 \%$ を占めた。男女比は およそ $2: 1$ であった。

3 ）異物の種類ではピーナッツが全体の約半 数を占めており, 食物は大半が 4 歳以下の乳幼 児であるのに対し, 非食物は年長児・成人に多 く認められた。

4）異物の介在部位は年齢に関係なく左に多 かった。

5 ）異物の介在日数は誤嬹当日に摘出され 
た例が最も多かったが，1 カ月以上の長期介在 例も11例認められた。

6 ) 摘出方法の検討では58例が硬性気管支 鏡， 2 例がファイバースコープ，2 例が開胸に より摘出され，自然喀出例は 6 例認められた。

7 ) 今回の検討した 69 例中，死亡例はなかっ た。

\section{文献}

1）庄村赤裸，金田正徳，鈴木俊郎・他：気管・気 管支異物，とくに開胸手術と死亡例を中心とし て. 耳喉, 51：113-119, 1979.

2 ) 田中 治, 柏木令子, 太田和博 - 他：X線透過 性下気道異物 25 症例の診断について。日気食会 報, 36:309-316, 1985 .

3 ) 牧 清人, 安岡義人, 原田 紀・他: 当教室 25 年間の気管・気管支異物の統計的観察。耳鼻臨 床，77増 2：666-671, 1984 .

4 ）山本真一郎, 板谷知已, 馬場駿吉：当教室 16 年 間の気管・気管支異物の臨床統計的観察. 日気 食会報，43：427-431, 1992.

5 ) 坂口正範，河原田和夫：当教室 21 年間の気管気 管支異物の統計的観察。日気食会報, 39：332338, 1988.

6 ）小林 良, 佐藤英治, 酒井利忠・他：食道抒よ び気管・気管支異物の統計的観察—当教室18年 間の集計一。耳鼻臨床，補27：170-182, 1988.

7 ) 中野幸治, 鮫島靖浩, 増山敬祐 - 他：最近 10 年 間の気道異物症例の検討. 日気食会報，44：813, 1993

8 ）矢部多加夫，小山 悟，平川治男 -他：当教室 11 年間の食道・下気道異物症例の臨床統計的検 討。日気食会報，46：13-20, 1995 .

9 ）上田隆志，衛藤幸男，柏木令子・他：当教室 15 年間の下気道・食道異物の統計的観察.耳鼻臨
床，補37：223-229, 1990 .

10）洲崎春海, 久木田尚仁, 久保田勇人 $\cdot$ 他：気道 異物の統計と診断法. JHONS, 9：471-475, 1993.

11）仁瓶誠五，樋渡章二，大八木章博 - 他：当院に おける気管気管支異物 10 年の統計的観察と興味 ある若于例について。耳鼻臨床，76増 1：753763, 1983.

12）金子省三，日野原正，秋山欣治・他：小坚気管 支異物の介在側について.日気食会報, $33: 31$ $36,1982$.

13）西条 茂, 富岡幸子, 高坂知節・他：Ventilation Bronchoscopeにより摘出した気道異物100症 例の統計的観察。日気食会報, 28：211-216, 1977.

14）井畑克朗，岩田重信，内藤健晴-他：当科20年 間における気管・気管支異物の統計的観察.耳 鼻臨床，補65：197-201, 1993.

15）粟田口省吾，宮野和夫，円山宏洋・他：気管 • 気管支異物63例の臨床的検討. 日気食会報, 31 : 315-321, 1980.

16) Jackson, C., and Jackson, C.L. : Bronchoesophagology, pp.68-109, W.B. Suanders Co., Philadelphia, 1950.

17）細沼秀生，高山乙彦，押尾良功・他：気道，食 道長期嵌入異物についての考察。日気食会報, $33: 334-339,1982$.

18）小倉義郎，安原晧三，遠藤洋一・他：気管気管 支異物の自然喀出について。日気食会報, 19： 126-130, 1968.

19）狩野季代, 安達裕一郎, 井手 稔 - 他：宮崎医 大および県立宮崎病院における気道・食道異物 の臨床統計的観察。日気食会報, 38：366-373, 1987.

20) Chatterji, S., and Chatterji, P.: The management of foreign bodies in air passages. Anaesthesia, $27: 390-395,1972$. 